\title{
Self-assessment and woman's health control location after gynaecological operations
}

\section{Samoocena i umiejscowienie kontroli zdrowia kobiet po przebytych operacjach ginekologicznych}

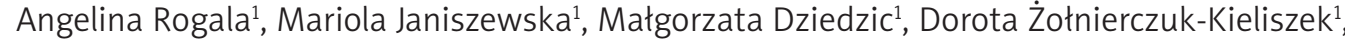 \\ Tomasz Blicharski
}

${ }^{1}$ Department Health Sciences, Chair of Public Health, Medical University of Lublin, Lublin, Poland Head of the Department: Prof. Teresa B. Kulik MD, PhD

${ }^{2}$ Chair and Department of Rehabilitation and Orthopaedics, Medical University of Lublin, Lublin, Poland

Head of the Department: Prof. Mirosław Jabłoński MD, PhD

Medical Studies/Studia Medyczne 2016; 32 (2): 86-95

Key words: women, gynaecological operations, health self-assessment, health control location.

Słowa kluczowe: kobiety, operacje ginekologiczne, samoocena zdrowia, umiejscowienie kontroli zdrowia.

\begin{abstract}
Introduction: Surgical treatment in gynaecology has a specific influence on a woman's life and has a psychological effect because of the organs involved. Self-assessment and women's health control location after gynaecological operation determine the treatment and rehabilitation process.

Aim of the research: Self-assessment and women's health control location after gynaecological operation evaluation was the aim of this study.

Material and methods: There were 167 women after gynaecological treatment evaluated. Patients were registered in the Obstetrics and Gynaecology department and the Gynaecology outpatient Clinic in Chełm Public Specialist Hospital. MHCL version B scale with polish adaptation (Z. Juszyński) and sociodemographic, self-evaluation, and health control questionnaires created by the authors were used. This analysis used Kołmogorow-Smirnow, U Mann-Whitney and Kruskal-Wallis tests. Confidence intervals of $p<0.05$ and $p<0.01$ were established. IBM SPSS Statistics software was used.

Results and conclusions: Most of the women after their gynaecological operations (61.1\%) revealed their health perception as good and only one (0.6\%) as poor. Over half of the patients self-assessed themselves as a valuable person (56.3\%) and womanlike (55.1\%), whilst a small number of patients stated as not attractive, impoverished, worse than others, useless, or worthless. The highest self-assessment scores were from women in early stages after their operation, e.g. from one month to one year after treatment $(\mathrm{M}=14.95)$. MHLC scale analysis showed that most of the patients overbalanced internal health self-control $(M=25.33)$, indicating that life control is dependent on the patient. Respondents who stated their health status as poor in every health control scale had higher results. Age and education had a significant influence on the MHCL and self-assessment scales $(p<0.001)$.
\end{abstract}

\section{Streszczenie}

Wprowadzenie: Operacje chirurgiczne przeprowadzane w ginekologii wywierają szczególny wpływ na życie i psychikę kobiet ze względu na narządy, które obejmują. Samoocena i poczucie umiejscowienia kontroli po zabiegu chirurgicznym determinują proces leczenia i rehabilitacji.

Cel pracy: Zbadanie samooceny i umiejscowienia kontroli zdrowia kobiet po przebytych operacjach ginekologicznych.

Materiał i metody: Badaniem objęto grupę 167 kobiet po przebytych operacjach ginekologicznych, będących pacjentkami Oddziału Położniczo-Ginekologicznego oraz poradni ginekologicznej w Samodzielnym Publicznym Wojewódzkim Szpitalu Specjalistycznym w Chełmie. Do badań zastosowano Skalę umiejscowienia kontroli zdrowia MHCL - wersja B (polska adaptacja: Z. Juczyński) oraz kwestionariusz ankiety własnego autorstwa dotyczący danych socjodemograficznych, samooceny, kontroli i stanu zdrowia. Do analizy statystycznej zastosowano test Kołmogorowa-Smirnowa, test $U$ Manna-Whitneya i test Kruskala-Wallisa. Przyjęto poziom istotności $p<0,05$ i $p<0,01$. Zastosowano oprogramowanie komputerowe IBM SPSS Statistics.

Wyniki i wnioski: Większość kobiet $(61,1 \%)$ po operacji ginekologicznej oceniła swój stan zdrowia jako dobry, tylko $1(0,6 \%)$ kobieta określiła stan zdrowia jako zły. Ponad połowa respondentek postrzegała siebie jako osoby wartościowe (56,3\%) oraz kobiece $(55,1 \%)$, a tylko niewielki odsetek kobiet uważał się za nieatrakcyjne, zubożałe, gorsze od innych, bezużyteczne czy 
bezwartościowe. Najwyższą samooceną charakteryzowały się kobiety w dość wczesnym okresie po operacji, czyli od miesiąca do roku $(\mathrm{M}=14,95)$. Analiza skali MHLC wykazała, że u ankietowanych przeważało wewnętrzne poczucie kontroli zdrowia $(\mathrm{M}=25,33)$ wskazujące, że kontrola nad własnym zdrowiem zależy od nich samych. Respondentki gorzej oceniające swój stan zdrowia we wszystkich skalach umiejscowienia kontroli zdrowia uzyskiwały stosunkowo wyższe wyniki. Wiek i wykształcenie istotnie różnicowały wyniki w zakresie skali MHCL oraz ogólnej samooceny $(p<0,001)$.

\section{Introduction}

Gynaecological operative interventions have a great impact on psychical and physical health. There were 1,122,000 patients operated on in obstetrics and gynaecology wards in 2013, from a total of 8.5 million persons operated on globally [1]. Women's health problems are commonly associated with procreation, commonly named "women's diseases". Health is a term that has multiple meanings, and it has many aspects in its structure. Disease results are connected not only with genital physical dysfunction but also have an influence on physical aspects [2].

Surgical operative procedures have a specific influence on women's life and psychics because of the organs involved in treatment. Fear is connected with correct decision choice, fear of anaesthesia, complications after treatment, dependence on other people, fear of cancer diagnosis, and long postoperative rehabilitation process. Many diseases and congenital genital defects require operative treatment. Sometimes operations are the only possibility for restoring proper function of this system. The aim of this operation type is to resect unnecessary genital areas involved in the disease process, restore correct function in congenital defects, and discard disease and trauma complications [3]. Body parts involved in the disease process that are connected with the feminine sense of what it means to lust, and to be attractive, and have stable self-evaluation [4]. Gynaecological operative interventions are commonly associated with internal disability fears. Postoperative wounds, even when not visible to other people, can destabilise the patient's own body picture and can decrease self-assessment. This problem can be associated with a lack of self-understanding and lack of disability self-acceptance. Woman can feel many fears and be upset because of global treatment processes. It consists of the fear of maintaining satisfactory physical contact, of having the possibility to have children and of being attractive and womanlike to their partner after treatment [5-7].

The most common indications for operative gynaecological treatments are: non-malignant and malignant neoplasms in the fertility system area, for example connected with ovaries, fallopian tubes, vagina, uterus cervix, and uterus, genital glands static disorders, congenital fertility organs disorders, appendages inflammatory tumours, minor pelvis endometriosis, and extra uterine pregnancy.

The second cause of death in Poland is malignant neoplasms [8]. Over $23 \%$ of deaths in 2011 were caused by malignant neoplasms. This is one of the main reasons for premature deaths of women before 65 years of age $(48 \%$ of deaths of middle aged women and $32 \%$ of deaths of young women). In regards to fertility system neoplasms, the most clinically important are: uterus cervix cancer, uterus cancer, and fallopian tube cancer [9]. The common treatment after such diagnosis is radical resection and invasive intervention, which is connected with an influence on women's psychics [10, 11].

Breast cancer was the first place registered malignant neoplasm in 2012 (22.2\%), the second is uterus malignant neoplasm (7.1\%), and the fifth place is ovary malignant neoplasm (4.6\%), followed by uterus cervix malignant neoplasm (3.6\%) [12].

Despite the action made by Population Prophylaxis Program and Cervix Uteri Cancer Early Diagnosis Program and simple diagnosis (cytological exam and colposcopy exam), early stages of cancer diagnosis and treatment seem to be insufficient and too low. Cancer of the cervix uteri is an important medical and social problem in Poland. According to this diagnosis, which is connected with young and middle aged women, there is a stable increase in incidence in Poland. Very important information is that this diagnosis is usually made in advanced stages of the disease. This sociologic problem is connected with low disease awareness and a lack of knowledge that this cancer can be successfully treated in early stage diagnosis. Another important problem is low awareness of prophylaxis [13].

Self-estimation and control necessity after genital surgical interventions is a valuable field of interest because of the increasing problems in various age groups of patients. Because of the intimate character of the disease, self-estimation and feeling of self-control have an important influence on the global treatment and rehabilitation process.

Self-estimation is the relationship with ourselves that has an influence on personal actions and an influence on mood. This presents the picture of the person with the summary of thoughts and judgements about their own intellect, look, character, interpersonal relationships, emotional maturity, and life aims selection [14].

Health status self-estimation is one of many elements, which the estimation of quality of life includes. Health status self-estimation has an influence on the method of stress management, the activity level, and social contact [15]. High self-estimation promotes longevity, good health, and provides a successful sexual life. The connection of self-estimation with health results in a connection of negative feelings experience 
created in failure and defeat reaction. According to the literature, low self-estimation results in patients reacting with health status exacerbations even when there is a positive event. Invalid reaction low self-estimation patients may decrease their immunological system reaction. Persons with high self-estimation when positively stimulated have a decrease in disease incidence, which results in a decrease in visits to the doctor's office. Positive feelings connected with life situations and events increase self-value feeling, releasing in this situation desired emotions [16]. Good health feeling has a positive influence on general life self-assessment. People with high health self-assessment are more active, have more future plans, and are more satisfied with life and situations that have happened during this time. Understated subjective selfassessment of their health status results in reduced activity and social life [17].

A sense of locus of control is recognised as one of the many dimensions of personality that form the functioning of a person, both in social life and in the different spheres of its activity. This relates, based on perception, to the influence on the self from the results of its action [18]. A sense of control is an important factor in regulating the functioning of a person in difficult situations [19]. A sense of locus of control can be classified into internal or external. When a person controls their own actions, looks for the reasons of their behaviour among internal factors, and has influence on strengthening, they have an internal locus of control. If the results of actions are interpreted by a person as a conditionality of random factors (other people, faith in luck, chance, fate), and not of their own capability, it is referred to as an external locus of control [20]. Further to health condition, internal locus of control is an expression of the belief for people with its immediate impact on the state, and external locus of control about the impact of external factors, e.g. doctors [21]. The internal health locus of control is more likely to initiate health behaviour that leads to better health [20]. Good physical condition and at the same time a life satisfaction depends on the locus of control. External locus of control is associated with dissatisfaction and depressive states, distinct from internal locus of control, which is associated with life satisfaction [22].

\section{Aim of the research}

The aim of this study is to investigate self-assessment and location of control health of women after surgical treatment in gynaecology.

\section{Material and methods}

The empirical material was collected using the following tools: Health Locus of Control Scale (Multidimensional Health Locus of Control - MHLC) -
B version K.A. Wallstona, B.S. Wallston, R. DeVellisa in adaptation: Z. Juczyńskiego and his own questionnaire.

The Polish adaptation MHCL Scale contains 18 statements relating to generalisation expectations and beliefs of respondents recognised in three dimensions of health locus of control:

- internal - indicating that the control over their own health depends on themselves,

- the impact of other - indicating that their own health depends on the influence of others, especially medical personnel,

- chance - on the state of health determined by chance or other external factors [23].

The tool used was a six-point scale, the scope of which included: from $1 \mathrm{p}$ - strongly disagree to $6 \mathrm{p}$ - strongly agree. The results are calculated to total up the key answers chosen by the respondents. The scope of points for each of the three scales is from 6 to 36 . The higher the score points, the stronger the confidence about the impact of a factor of health. The basis of the scale is the belief that internal sense of health locus of control behaviour is conducive to health, and it is supposed that a person with an internal locus of control LOC has a greater sense of responsibility for their health [23].

The questionnaire by own authorship consisted of 30 closed questions, with 20 questions that were disjunctive, with a choice of only one answer, seven questions that were conjunctive with the ability to select more than one answer, and three questions alternative type 'yes' or 'no'. The questionnaire was sorted according to thematic areas: questions from 1 to 7 related to self-assessment of women, and from 8 to 30 control and health state. To calculate a general self-assessment level of respondents, a key was created for their own use by the authors of the questionnaire. Each test person should get a certain number of points attributed to a specific question, then the result is summed. In the self-assessment scale a respondent could receive from -5 to 24 points. The more points, the higher the self-assessment. Additionally, respondents were asked six questions about socio-demographic data.

There were 167 women evaluated after gynaecological treatment. Patients were registered in the Obstetrics and Gynaecology department and Gynaecology outpatient Clinic in Chełm Public Specialist Hospital in the period from January to June 2015. Almost 39\% of the women surveyed were aged from 20 to 35 years, $24.6 \%$ of the respondents were between 36 and 45 years of age, $23.4 \%$ from 46 to 55 , and $13.2 \%$ over 55 years. Nearly half of the respondents (46.7\%) were during the first week after surgery. A significant percentage $(40.1 \%)$ of the tested ranged from one to five years after gynaecological surgery. Other women (13.2\%) ranged from one month to 1 year af- 
ter surgery. The largest part of respondents (66.5\%) had a history of abdominal surgery, while $33.5 \%$ had history of vaginal surgery. More than half of the respondents (56.9\%) lived in the city, and $43.1 \%$ in rural areas. Considering the level of education, nearly half of the test women $(45.2 \%)$ had secondary education, and one in three had higher education (33.1\%). Far fewer of the respondents had a vocational education (13.3\%), and the least had primary education (8.4\%). The vast majority of the respondents were married women $(70.1 \%)$, and every fourth tested $(26.3 \%)$ was unmarried. Widows made up the other $3.6 \%$ of the test group. As a source of income, nearly half of respondents (47.3\%) indicated professional work, 15\% their own business, and $19.2 \%$ annuity or pension. Unemployed accounted for $18.6 \%$ of the respondents. As for the social-living conditions, nearly half of respondents (46.7\%) assessed it as good, $27.5 \%$ as very good, and $25.1 \%$ as average. Regarding bad condition, only one person complained $(0.6 \%)$.

\section{Statistical analysis}

The collected empirical material was analysed both descriptively and statistically. The tests used were: Kołmogorow-Smirnow Test, $U$ Mann-Whitney Test, and Kruskal-Wallis Test. Significance levels of $p<0.05$ and $p<0.01$ suggested the existence of statistically significant relationship. Database and statistical tests were carried out using IBM SPSS Statistics software.

\section{Results}

The surveyed were asked questions about the subjective judgment of health after surgery, control, and feelings and behaviours resulting from the fact that they were after surgery. The vast majority of the respondents (61.1\%) assessed their health after gynaecological surgery as good, and $26.9 \%$ as acceptable. $11.4 \%$ of respondents assessed their health as very good, while only one woman (0.6\%) among the 167 respondents assessed her health as poor. Nearly half of the respondents (48.5\%) after surgery felt fear and anxiety, while $43.7 \%$ felt relief. No emotion was felt by only $7.8 \%$ of the tested women. Most of the respondents (64.1\%) had no negative emotions related to the operation. The most signifying negative emotion was lesser self-assessment (16.2\% of respondents), loss of attractiveness (13.8\% of respondents), loss of satisfactory sexual intercourse (11.4\% of respondents), and loss of femininity (7.2\% of respondents). During analysis of the question concerning positive emotion after the surgery, most of the women $(72.1 \%)$ indicated the hope for a better tomorrow. Far fewer respondents felt: pride and admiration for themselves with the decision to have surgery (27.1\%), satisfaction and the desire to enjoy their life as much as possible (25.7\%), and joy (17.9\%). No positive emotions were felt by $20.7 \%$ of the women. Difficulties with self-acceptance after surgery was felt by $7.8 \%$ of the women. Frequent episodes of depression during one month after a surgery was reported by $12 \%$ of respondents. These episodes were reported sometimes by $12.6 \%$, and $19.2 \%$ of women rarely, while patients never experiencing such episodes totalled 21\% of respondents. Around 36\% of the surveyed right after surgery were unable to respond to the question concerning depression.

In assessing behavioural changes in women during the first year after surgery, it was found that the vast majority of respondents (73.3\%) did not see any changes in their behaviour in this period of time. The tendency for loneliness and closing in on themselves, and avoidance of social contacts were observed at home by $18.5 \%$ of respondents, a strong emotional reaction to the criticism by $17 \%$, avoiding ambitious goals by $14.8 \%$, rolling out with new tasks $11.9 \%$, unfavourable comparisons to others $11.9 \%$, undervaluing their own advantages and skills $10.4 \%$, and no tendency for self-actualisation and a minimalist attitude to life $8.1 \%$ (Table 1).

Nearly half of the respondents (47.3\%) stated that their quality of life after surgery has improved, $45.5 \%$ chose the answer 'do not know', while $7.2 \%$ did not notice that their quality of life had improved. Most of the respondents $(67.1 \%)$ declared an improvement of mood after the treatment. Mood was not improved in $12.6 \%$ of tested persons, and $20.4 \%$ of respondents did not wonder about it.

By taking the test of knowing the self-assessment after gynaecological surgery, the surveyed were asked seven questions about this topic. After analysing the questions of how respondents perceive themselves in the context of their history of surgery it was shown that more than half of the respondents considered themselves as a feminine person (56.3\%), valuable (55.1\%), confident (21.6\%), attractive (21\%), and lacking complexes (12.6\%). The importance is among five positive values and five negative values; all five positive values were more frequently displayed. Only $7.8 \%$ of women perceive themselves as unattractive, $3.0 \%$ as impoverished, $1.8 \%$ as inferior to other women, $1.8 \%$ as useless, and $0.6 \%$ as worthless (Table 2 ).

When analysing, the results demonstrated that the most of the respondents (73.1\%) were satisfied with themselves, while $13.8 \%$ were definitely satisfied. Only $11.4 \%$ of women were dissatisfied, and $1.8 \%$ definitely dissatisfied. $19.8 \%$ of tested women definitely liked themselves, and $67.7 \%$ of respondents liked themselves. $10.8 \%$ of respondents did not like themselves, whilst $1.8 \%$ definitely did not like themselves. As many as 2 in 3 surveyed (66.5\%) agreed that they would like to have more respect for themselves, every fourth tested (25.7\%) strongly agreed with this, and $7.8 \%$ disagreed with this statement. As 
Table 1. Behavioural change during the first year after surgery

\begin{tabular}{|lccc|}
\hline $\begin{array}{l}\text { What changes in behaviours did you perceive in your life during } \\
\text { the first year after surgery? }\end{array}$ & \multicolumn{2}{c}{ Answer } & \%bservation \\
\cline { 2 - 3 } Not realize any changes & 99 & 44.2 & 73.3 \\
$\begin{array}{l}\text { The tendency to loneliness and closing in on yourself, avoidance } \\
\text { of social contacts }\end{array}$ & 25 & 11.2 & 18.5 \\
Strong emotional reaction to the criticism & 23 & 10.3 & 17.0 \\
Avoiding ambitious goals & 20 & 8.9 & 14.8 \\
Rolling out with new tasks & 16 & 7.1 & 11.9 \\
Unfavourable comparisons to the other & 16 & 7.1 & 11.9 \\
Undervalue their own advantages, skills & 14 & 6.3 & 10.4 \\
No tendency to self-actualization, a minimalist attitude to life & 11 & 4.9 & 8.1 \\
In total & 224 & 100.0 & 165.9 \\
\hline
\end{tabular}

$\%$ Observation does not add up to 100 because respondents can indicate more than one answer.

Table 2. The perception of ourselves

\begin{tabular}{|lccc|}
\hline How do you perceive yourself? & \multicolumn{2}{c}{ Answers } & \% Observe \\
\cline { 2 - 3 } Femininity & $N$ & $\%$ & 56.3 \\
Valuable & 94 & 31.0 & 55.1 \\
Confident & 92 & 30.4 & 21.6 \\
Attractive & 36 & 11.9 & 21.0 \\
Lacking complexes & 35 & 11.6 & 12.6 \\
Unattractive & 21 & 6.9 & 7.8 \\
Impoverished & 13 & 4.3 & 3.0 \\
Inferior to other women & 5 & 1.7 & 1.8 \\
Useless & 3 & 1.0 & 1.8 \\
Worthless & 3 & 1.0 & 0.6 \\
In total & 1 & 0.3 & 181.4 \\
\hline
\end{tabular}

$\%$ Observation does not add up to 100 because respondents can indicate more than one answer.

many as $40.7 \%$ of respondents definitely had many reasons to be proud of themsleves, while $53.3 \%$ had many such reasons. $4.8 \%$ of respondents did not have many reasons to be proud of themselves, and $1.2 \%$ of the women definitely did not have those reasons. With the statement 'Sometimes I feel useless' 62.3\% of surveyed disagreed, $2.4 \%$ definitely disagreed, $24.6 \%$ agreed, and $10.8 \%$ of the women definitely agreed. Very often in their own forces they believed were $35.3 \%$ of women, often numbered $44.3 \%$ of the respondents, $13.2 \%$ rarely, sometimes $4.8 \%$, and $2.4 \%$ did not believe in their own strength ever.
The MHCL Scale contains 18 statements relating to generalisation expectations and beliefs of respondents recognised in three dimensions of health locus of control. Table 3 shows the basic descriptive statistics scales used in the study. As seen in surveyed women with history of the gynaecological operation treatment slightly prevailed internal sense of health control; this suggests that the control over their own health depends on them $(\mathrm{M}=25.33)$. In the dimension concerning the effect of others, it suggests that their health is dependent on the influence of other people, especially medical personnel, thus obtaining 
Table 3. Basic descriptive statistics of scales used in the test

\begin{tabular}{|lccccc|}
\hline MHCL and self-assessment & $\boldsymbol{N}$ & Min. & Max. & M & SD \\
Internal & 165 & 11 & 36 & 25.33 & 5.52 \\
Influence others & 167 & 7 & 36 & 23.74 & 6.63 \\
Chance & 167 & 6 & 36 & 22.92 & 6.37 \\
In total self-assessment & 167 & 3 & 21 & 13.33 & 2.76 \\
\hline
\end{tabular}

the result $\mathrm{M}=23.74$. The lowest result was obtained in the chance of the scale (the state of health determined by chance or other external factors) $-\mathrm{M}=$ 22.92. The average result in the self-assessment scale is $\mathrm{M}=13.33$. The lowest result in the study group is 3, and the highest is 21 points. These results are shown in Table 3.

When analysing the results about self-assessment after surgery, it was found that the highest self-assessment characterised was by women who were in the period from 1 month to 1 year after surgery $(\mathrm{M}=14.95)$, and the lowest was by women between one year to five years after surgery $(M=12.36)$. The difference between all compared groups was statistically significant $(p<0.001)$ (Table 4$)$.

When analysing results of the study, it was found that the current state of health of women after gynaecological surgeries highly significantly differentiated concerning their locus of control $(p<0.001)$. What is interesting in all of the scales of the worse health is the higher the result, the stronger the belief in the influence of a factor on the state of health. The differences between all groups in all scales are statistically significant (Table 5).
Quality of life after surgery showed significantly highly differentiated results in all scales MHCL $(p<$ 0.001). As it turned out, people whose quality of life in their opinion has improved achieved significantly lower scores on all scales; the MHCL of people who did not identify the improvement of quality of life, or that the question 'How do you rate your quality of life after the surgery?' chose the answer 'do not know'. The data is presented in Table 6 .

Age showed significantly highly differentiated results in subscales of MHCL and in the results of the overall self-assessment of women $(p<0.001)$. As it turned out, the respondents who were between 20 and 35 years of age had a significantly lower sense of internal control of health compared to the rest of the surveyed $(\mathrm{M}=21.86)$, similarly to the case of the influence of other people on the state of health and the role of case $(\mathrm{M}=19.45$ and $\mathrm{M}=18.72)$. In addition, the scale of the influence of other, significantly better results were achieved by the oldest respondents $(\mathrm{M}=30.14)$ of women who are in the range of 36 to 45 years. In turn, in the self-assessment scale, significantly lower results were achieved by respondents in the range of 46 to 55 years of age $(\mathrm{M}=13.08)$ com-

Table 4. The time from the operation and self-assessment

\begin{tabular}{|c|c|c|c|c|c|}
\hline \multirow[t]{2}{*}{ How much time has passed since the operation? } & \multirow[t]{2}{*}{$M$} & \multirow[t]{2}{*}{ SD } & \multicolumn{2}{|c|}{ Kruskal-Wallis Test } & \multirow{2}{*}{$\begin{array}{l}\text { Important } \\
\text { differences }\end{array}$} \\
\hline & & & $H$ & $p$ & \\
\hline $1-7$ days $(1)$ & 13.71 & 2.91 & \multirow{3}{*}{18.002} & \multirow{3}{*}{$<0.001$} & $1-2$ \\
\hline From 1 months to 1 year (2) & 14.95 & 0.90 & & & $1-3$ \\
\hline $1-5$ years $(3)$ & 12.36 & 2.63 & & & $2-3$ \\
\hline
\end{tabular}

Table 5. Self-assessment of health and health locus of control

\begin{tabular}{|c|c|c|c|c|c|}
\hline \multirow[t]{2}{*}{ How much time has passed since the operation? } & \multirow[t]{2}{*}{$M$} & \multirow[t]{2}{*}{ SD } & \multicolumn{2}{|c|}{ Kruskal-Wallis Test } & \multirow{2}{*}{$\begin{array}{l}\text { Important } \\
\text { differences }\end{array}$} \\
\hline & & & $H$ & $p$ & \\
\hline 1-7 days (1) & 13.71 & 2.91 & \multirow{3}{*}{18.002} & \multirow{3}{*}{$<0.001$} & $1-2$ \\
\hline From 1 months to 1 year (2) & 14.95 & 0.90 & & & $1-3$ \\
\hline $1-5$ years (3) & 12.36 & 2.63 & & & $2-3$ \\
\hline
\end{tabular}


Table 6. Quality of life after surgery and health locus of control

\begin{tabular}{|c|c|c|c|c|c|}
\hline \multirow[t]{2}{*}{ How much time has passed since the operation? } & \multirow[t]{2}{*}{ M } & \multirow[t]{2}{*}{ SD } & \multicolumn{2}{|c|}{ Kruskal-Wallis Test } & \multirow{2}{*}{$\begin{array}{l}\text { Important } \\
\text { differences }\end{array}$} \\
\hline & & & $H$ & $p$ & \\
\hline 1-7 days (1) & 13.71 & 2.91 & \multirow{3}{*}{18.002} & \multirow{3}{*}{$<0.001$} & $1-2$ \\
\hline From 1 month to 1 year (2) & 14.95 & 0.90 & & & $1-3$ \\
\hline $1-5$ years $(3)$ & 12.36 & 2.63 & & & $2-3$ \\
\hline
\end{tabular}

pared to the respondents from 20 to 35 years $(\mathrm{M}=$ 13.54) and from 36 to 45 years of age (13.76). The results are presented in Table 7 .

The level of education showed significantly differentiating MHCL results $(p<0.001)$ and total self-assessment ( $p=0.001)$. As it turned out, respondents with higher education achieved significantly higher results on a scale of internal health locus of control $(\mathrm{M}=29.45)$ and in the chance scale $(\mathrm{M}=27.58)$ than all other respondents. However, on the scale of the influence of others, people with higher education $(\mathrm{M}=$ 27.95) achieved significantly better results than those with primary education $(\mathrm{M}=24.00)$ and secondary education $(\mathrm{M}=20.03)$.
People with vocational education achieved significantly better results than those with secondary education. In turn, those who studied with secondary education $(\mathrm{M}=14.32)$ had significantly higher levels of self-assessment compared to vocational education of the respondents $(\mathrm{M}=11.73)$ and higher $(\mathrm{M}=12.55)$ (Table 8$)$.

\section{Discussion}

Based on research conducted through the questionnaire by their own hand, they showed that most of the respondents rated their health as good. Similar research on health self-assessment was conducted in 2010 by the Central Statistical Office, which showed that $28 \%$ of women rated their health as good, and

Table 7. Age and health locus of control and self-assessment

\begin{tabular}{|c|c|c|c|c|c|c|c|c|c|c|c|}
\hline \multirow{3}{*}{$\begin{array}{l}\text { MHCL and } \\
\text { self-assessment }\end{array}$} & \multicolumn{8}{|c|}{ Age [years] } & \multicolumn{2}{|c|}{ Kruskal-Wallis test } & \multirow{3}{*}{$\begin{array}{l}\text { Important } \\
\text { differences }\end{array}$} \\
\hline & \multicolumn{2}{|c|}{$20-35(1)$} & \multicolumn{2}{|c|}{$36-45(2)$} & \multicolumn{2}{|c|}{$46-55(3)$} & \multicolumn{2}{|c|}{ Over 55 (4) } & \multirow[t]{2}{*}{$H$} & \multirow[t]{2}{*}{$p$} & \\
\hline & $M$ & SD & $M$ & SD & $M$ & SD & $M$ & SD & & & \\
\hline Internal & 21.86 & 5.51 & 26.88 & 1.99 & 28.39 & 4.10 & 27.45 & 6.70 & 43.110 & $<0.001$ & $\begin{array}{c}1-2,1-3 \\
1-4\end{array}$ \\
\hline Influence others & 19.45 & 7.19 & 24.41 & 2.66 & 26.56 & 4.44 & 30.14 & 5.01 & 53.679 & $<0.001$ & $\begin{array}{l}1-2,1-3 \\
1-4,2-4\end{array}$ \\
\hline Chance & 18.72 & 6.19 & 24.68 & 3.81 & 26.26 & 4.58 & 26.09 & 6.87 & 40.269 & $<0.001$ & $\begin{array}{c}1-2,1-3 \\
1-4\end{array}$ \\
\hline $\begin{array}{l}\text { In total self- } \\
\text { assessment }\end{array}$ & 13.54 & 2.99 & 13.76 & 2.69 & 13.08 & 2.39 & 12.36 & 2.66 & 16.936 & $<0.001$ & $1-3,2-3$ \\
\hline
\end{tabular}

Table 8. Education and health locus of control and self-assessment

\begin{tabular}{|c|c|c|c|c|c|c|c|c|c|c|c|}
\hline \multirow{3}{*}{$\begin{array}{l}\text { MHCL and } \\
\text { self-assessment }\end{array}$} & \multicolumn{8}{|c|}{ Education } & \multicolumn{2}{|c|}{ Kruskal-Wallis test } & \multirow{3}{*}{$\begin{array}{l}\text { Important } \\
\text { differences }\end{array}$} \\
\hline & \multicolumn{2}{|c|}{ Primary (1) } & \multicolumn{2}{|c|}{ Vocational (2) } & \multicolumn{2}{|c|}{ Secondary (3) } & \multicolumn{2}{|c|}{ Higher (4) } & \multirow[t]{2}{*}{$H$} & \multirow[t]{2}{*}{$p$} & \\
\hline & $M$ & SD & $M$ & SD & $M$ & SD & $M$ & SD & & & \\
\hline Internal & 24.86 & 4.62 & 23.48 & 4.31 & 22.76 & 5.25 & 29.45 & 3.75 & 56.595 & $<0.001$ & $\begin{array}{l}1-4,2-4 \\
3-4\end{array}$ \\
\hline Influence others & 24.00 & 6.03 & 24.95 & 5.77 & 20.16 & 6.69 & 27.95 & 3.86 & 46.960 & $<0.001$ & $\begin{array}{l}1-4,2-3 \\
3-4\end{array}$ \\
\hline Chance & 20.86 & 2.91 & 22.59 & 4.91 & 20.03 & 6.43 & 27.58 & 4.65 & 50.587 & $<0.001$ & $\begin{array}{c}1-4,2-4 \\
3-4\end{array}$ \\
\hline $\begin{array}{l}\text { In total self- } \\
\text { assessment }\end{array}$ & 13.50 & 1.40 & 11.73 & 4.21 & 14.32 & 2.18 & 12.55 & 2.52 & 41.182 & $<0.001$ & $2-3,3-4$ \\
\hline
\end{tabular}


most even as very good. In the international scale the largest percentage of women who assess their condition as very good is enjoyed by Denmark, the Netherlands, Belgium, and Switzerland [1].

Relating to our own results, it is worth noting that the study of women having an internal locus of control health rated their health at a good level. In research conducted by Szczepańska and Lipowski, [24] of 470 people from the province of Pomorskie, it was shown that respondents with a greater indicator of internal locus of control health rated well above their health and physical condition. Confirmation of these results can be found in studies by Helmer et al. [25], researching health and behaviour of health among people living in the Rhineland (Germany), and in research by Aflakseir and ZarrinPour [26], studying patients with type 2 diabetes. The research demonstrated that a greater sense of responsibility for their own health is associated with an internal locus of health control. Similar conclusions were reached by Piasecka et al. [27]. Contending research among students of the Medical University of Lublin and Warszawa in 2008 demonstrated that the biggest impact on health comes from an internal dimension of control, while the influence of others and chance have a much lower value.

The genital disease and women staying in the gynaecological department is, for the majority, a great experience and a serious mental load. Our own study has shown that only $21 \%$ of respondents had never experienced depression, while in over $12 \%$ of women during the first month after surgery, depression appeared quite often. Similar conclusions were reached by Jawor et al. [28] as an effect of the study conducted among women with hysterectomies. The authors maintain that the early postoperative period is extremely difficult for women and it requires attention from medical personnel. No action striving to develop a depressive disorder at the right time can promote the intensification and consolidation thereafter. Carr et al. [29], researching a group of 85 women with history of gynaecological surgery treatment, maintain that long-standing take on negative emotions by patients in the preoperative period may be the reason for depression, especially in the 2 to 4 days after surgery. Similar to the results obtained with the test given by Wojnar et al. studying the incidence of depression among 2262 women aged $45-55$ years, who were treated for gynaecological diseases. From these studies, it was shown that the more severe symptoms of depression were noticed by respondents after gynaecological surgery and in women treated in the gynaecological department. The negative influence of gynaecological operations on the psyche of women was also proven by Skrzypulec et al. analysing a group of 230 perimenopausal women treated from June 2001 to March 2002 in the Diagnostic Centre for Women's Health in Katowice [30, 31]. Rannestad et al., after carrying out a study of a group of women who had undergone gynaecological surgery procedures, paid attention to the increase in sleeping disorders presented by the respondents. Nonetheless, no changes of mental health (anxiety disorders or mental disorders) among those respondents were found [32]. On the other hand, according to the results obtained by Wang et al., who studied 105 Chinese women after hysterectomy, only $4.8 \%$ of these women were diagnosed with depression after the surgery [33].

Currently, researchers are interested in the issues of quality of life without which it is difficult to imagine the development and functioning of contemporary medicine $[34,35]$. The studies of the quality of life of patients after surgical procedures will be used to develop better and more effective current medical standards [36].

The analysis of the results of our own research demonstrates that less than half of the respondents $(47 \%)$ felt an improvement in their quality of life after gynaecological surgery. On the grounds of making research among most respondents just after surgery, as many as $45.5 \%$ were unable to determine whether their quality of live improved. Similar results were shown by Pang et al. [37], i.e. in a group of patients after surgery with the use of a TOT tape, $67 \%$ of respondents noticed the improvement in their of quality of life after the operation. Giberti et al. [38] researched the level of patient satisfaction after gynaecological surgery using a tape of the TOT 2 years after the treatment, and they gained $92 \%$ satisfaction from operated women, while as many as $88 \%$ of patients rated their quality of life after surgery as very high. A similar level of satisfaction (approx. 78\%) was shown in Roumegue're [39] studies on the improvement of quality of life after one year of surgery. The research conducted on 111 women by Rannestad et al. who wanted to compare the level of quality of life before and after hysterectomy procedure showed that the women's quality of life was worse in the period before the operation than after 6 and 12 months following the surgical procedure [40]. Lambden et al. [41], who studied the women's mood and life satisfaction in the period before and after surgical procedure drew the conclusions about the improvement of the women's mood as the time after the operation increased (from $88 \%$ after 4 months to $93 \%$ after 11 months).

Self-assessment, self-acceptance and self-perception occupy an important location in the structure of the human personality. The results of questionnaires showed that over half of the respondents considers themselves as feminine (56.3\%) and of value (55.1). A slightly smaller amount of women gave the answer 'self-confident', 'attractive', or 'lacking complexes'. Test results showing a slightly lower level of self-assessment were from Rostowska and Walęcka-Matyja studying 140 women aged from 30 to 49 years after mastectomy or skin diseases. In their research the authors indicated that for people whose appearance has been adversely 
altered as a result of the disease process it is important to have the influence of the doctor and a psychologist, as well as people close to the patient [14]. The large amount of anxiety and depressive reactions in a patient may contribute to the occurrence of complications in the process of treatment and recovery. The study demonstrated that nearly half of respondents $(48.5 \%)$ after surgery felt fear and anxiety. The level of fear in patients undergoing surgery in the pelvic area studied by Billert et al. [42] showing evidence of a very high level of fear studied perioperative. ŁepeckaKlusek et al. [43], based on data obtained from studies conducted among patients waiting for gynaecological surgery, showed that the concerns of women were i.a.: pain, $26.7 \%, 19.1 \%$ postoperative complications, loss of femininity $8.4 \%$, loss of fertility $8.1 \%$, separation from family $6.8 \%$, and $3.3 \%$ job loss. In the contrary to the previous studies the results of research by Wang et al. indicated very low percentage of women after hysterectomy experiencing anxiety (1.9\%).

\section{Conclusions}

Most women after gynaecological surgery assessed their health as good; only one woman among 167 respondents identified her health as poor. More than half of the respondents perceived themselves as valuable and feminine, and only a small percentage considered themselves to be impoverished, worse than other women, useless, or worthless. Time after gynaecological surgery is important for the formation of self-assessment. Interestingly, the highest self-assessment was characterised by women in a fairly early period after the operation, i.e. from a month to a year. Respondents were slightly favourable on the internal sense of health control, indicating that the control over their own health depends on them. Studies suggest that the case, or other external factors is the least decided on the state of health. The health status significantly differentiated health locus of control women with a history of gynaecological surgery. Respondents assessing their health status less favourably, at all scales, health locus of control, inspection are given relatively higher scores. Age and education significantly differentiated results on a scale MHCL and the results of the overall self-assessment.

\section{Conflict of interest}

The authors declare no conflict of interest.

\section{References}

1. Główny Urząd Statystyczny Zdrowie i ochrona zdrowia 2013 http://stat.gov.pl/obszary-tematyczne/zdrowie/ zdrowie/zdrowie-i-ochrona-zdrowia-w-2013-r-,1,4.html (z dnia 12.01.2015 r.)

2. Pawłowski R, Dutkiewicz R, Winiarczyk T. Znaczenie aktywności fizycznej i diety w życiu studentek. Studia Medyczne 2015; 31: 194-9.
3. Opala T. Ginekologia - podręcznik dla położnych, pielęgniarek i fizjoterapeutów. PZWL, Warsaw 2006.

4. Wilczak M, Mojs E, Samulak D, Michalska MM, Ziarko M, Kaczmarek $Ł$. Wpływ operacji ginekologicznych na stopień zaburzeń snu oraz emocji u kobiet $\mathrm{w}$ wieku okołoi pomenopauzalnym. Prz Menopauz 2011; 5: 393-9.

5. Bielecka A. Statystyka w zarządzaniu. Opis statystyczny, Wydawnictwo Wyższej Szkoły Przedsiębiorczości i Zarządzania im. Leona Koźmińskiego. Warsaw 2001.

6. Pilewska A, Jakiel G, Wenecki W. Operacja ginekologiczna jako sytuacja stresująca - potrzeba wsparcia w okresie okołooperacyjnym. Zdr Publ 2007; 117: 191-5.

7. Sevil U, Ertem G, Kavlak O, Coban A. The lonliness level of patients with gynecological cancer. Int J Gynecol Cancer 2006; 16 (Suppl. 1): 472-7.

8. Woźniewski M. Kultura fizyczna w życiu ludzi chorych na nowotwory złośliwe. Adv Clin Exp Med 2002; 11: 103-8.

9. Didkowska J, Wojciechowska U, Zatoński W. Nowotwory złośliwe w Polsce w 2011 roku. Centrum Onkologii. Instytut im M. Skłodowskiej-Curie, Warsaw 2013.

10. Trzebiatowska I. Zaburzenia psychiczne w chorobie nowotworowej. Psychoonkologia, Krakow 2000.

11. Derogatis LR, Morrow GR, Fetting J, Penman D, Piasetsky S, Schmale AM, Henrichs M, Carnicke CL Jr. Prevalence of psychiatric disorders among cancer patients. JAMA 1983; 249: 751-7.

12. Wojciechowska U, Didkowska J, Zatoński W. Nowotwory złośliwe w Polsce w 2012 roku. Centrum Onkologii. Instytut im M. Skłodowskiej-Curie, Warsaw 2012.

13. Kornafel J. Nowotwory szyjki macicy. Centrum Medyczne Kształcenia Podyplomowego, Warsaw 2011.

14. Rostowska T, Walęcka-Matyja K. Obraz siebie i poziom samooceny kobiet po amputacji piersi oraz kobiet ze schorzeniami skóry - analiza porównawcza. Psychoonkologia 2003; 7: 1-13.

15. Kwapisz U, Grzko G, Majchrzak B, Głogowski J. Zdrowotne i psychospołeczne aspekty funkcjonowania osób w starszym wieku. Piel XXI wieku 2005; 4: 79-82.

16. Dzwonkowska I, Łaguna M, Lachowicz-Tobaczek K. Samoocena i jej pomiar. Polska adaptacja skali SES M. Rosenberga. Pracownia Testów Psychologicznych, Warsaw 2008.

17. Sułowska M. Psychologia starzenia się i starości. PWN, Warsaw 1989.

18. Adame DD, Johnson TC. Physical fitness, body image, and locus of control in college freshman men and women. Percept Mot Skills 1989; 6: 400-2.

19. Wrześniewski K. Psychologiczne uwarunkowania powstawania i rozwoju chorób somatycznych. Psychologia. Gdańskie Wydawnictwo Psychologiczne, Gdańsk 2000.

20. Słomko Z. Ginekologia. PZWL, Warsaw 2008.

21. Juczyński Z. Przekonania i oczekiwania wyznacznikami zachowań związanych ze zdrowiem. Wydawnictwo Uniwersytetu Łódzkiego, Lodz 2003.

22. Kościelak R. Poczucie umiejscowienia kontroli i przekonania o własnej skuteczności w zdrowiu i chorobie. Oficyna Wydawnicza „Impuls”, Krakow 2010.

23. Kurowska K, Różańska O. Zachowania zdrowotne a umiejscowienie kontroli zdrowia u osób z rozpoznaniem kamicy żółciowej. Piel Chir Angiol 2014; 4: 35-40.

24. Jastrzębski Z, Kalka K. Teoria i praktyka wychowania fizycznego i sportu. Wyższa Szkoła Sportowa, Lodz 2014.

25. Helmer SM, Krämer A, Mikolajczyk RT. Health-related locus of control and health behaviour among university 
students in North Rhine Westphalia, Germany. BMC. Res Notes 2012; 5: 1-8.

26. Aflakseir A, ZarrinPour R. Predicting adherence to diet regimen based on health locus of control: a cross sectional study. IJDO 2013; 5: 71-6.

27. Piasecka H, Nowicki G, Ślusarska B. Sposób żywienia i umiejscowienie kontroli zdrowia $\mathrm{w}$ grupie studentów medycyny. Pielęgniarstwo XXI Wieku 2014; 2: 18-9.

28. Jawor M, Dimter A, Marek K. Zaburzenia depresyjno-lękowe $\mathrm{u}$ kobiet po histerektomii - badania własne. Psychiatr Pol 2001; 35: 771-80.

29. Carr E, Thomas V, Wilson-Barnet J. Patient experiences of anxiety, depression and acute pain after surgery: a longitudinal perspective. Int J Nurs Stud 2005; 42: 521-30.

30. Skrzypulec V, Drosdzol A, Ferensowicz J, Nowosielski K. Ocena wybranych aspektów życia psychicznego i seksualnego kobiet w okresie okołomenopauzalnym. Ginekol Prakt 2003; 11: 26-34.

31. Skrzypulec V, Naworska B, Drosdzol A. Analiza wpływu objawów klimakterycznych na funkcjonowanie i jakość życia kobiet w okresie okołomenopauzalnym. Prz Menopauz 2007; 6: 96-101.

32. Rannestad T, Eikeland OJ, Helland H, Qvarnström U. Are the physiologically and psychosocially based symptoms in women suffering from gynecological disorders alleviated by means of hysterectomy? J Womens Health Gend Based Med 2001; 10: 579-87.

33. Wang XQ Lambert CE, Lambert VA. Anxiety, depression and coping strategies in post-hysterectomy Chinese women prior to discharge. Int Nurs Rev 2007; 54: 271-9.

34. Trögner J. Physical activities and rehabilitation. Ther Umsch 2008; 65: 459-62.

35. Evangelista LS, Dracup K, Doering L, Moser DK, Kobashigawa J. Physical activity patterns in heart transplant women. J Cardiovasc Nurs 2005; 20: 334-9.

36. Morris KS, McAuley E, Motl RW. Self-efficacy and environmental correlates of physical activity among older women and women with multiple sclerosis. Health Educ Res 2008; 23: 744-52.

37. Pang MW, Chan LW, Yip SK. One year urodynamic outcome and quality of life in patients with concomitant tension-free vaginal tape during pelvic floor reconstruction surgery for genitourinary prolapse and urodynamic stress incontinence. Int Urogynecol J Pelvic Floor Dysfunct 2003; 14: 256-60.

38. Giberti C, Gallo F, Cortese P, Schenone M. Transobturator tape for treatment of female stress urinary incontinence: objective and subjective results after a mean follow-up of two years. Urology 2007; 69: 703-7.

39. Roumeguère T, Quackels T, Bollens R, de Groote A, Zlotta A, Bossche MV, Schulman C. Trans-obturator vaginal tape (TOT) for female stress incontinence: one year follow-up in 120 patients. Eur Urol 2005; 48: 805-9.

40. Rannestad T, Eikeland OJ, Helland H, Qvarnström U. The quality of life in women suffering from gynecological disorders is improved by means of hysterectomy. Acta Obstet Gynecol Scand 2001; 80: 46-51.

41. Lambden MP, Bellamy G, Ogburn-Russell L, Preece CK, Moore S, Pepin T, Croop J, Culbert G. Women's sense of well-being before and after hysterectomy. J Obstet Gynecol Neonatal Nurs 1997; 26: 540-8.

42. Billert H, Adamski D, Gaca M, Miluska J, Breborowicz G. Poziom lęku w okresie okołooperacyjnym u pacjentek ginekologicznych a nałóg palenia tytoniu - doniesienie wstępne. Prz Lek 2004; 61: 1035-9.

43. Łepecka-Klusek C, Pilewska-Kozak AB, Syty K, Tkaczuk-Włach J, Szmigielska A, Jakiel G. Oczekiwanie na planowaną operację ginekologiczną w ocenie kobiet. Ginekol Pol 2009; 80: 699-703.

\section{Address for correspondence:}

\section{Mariola Janiszewska}

Department Health Sciences

Chair of Public Health

Medical University of Lublin

ul. Chodźki 1, 20-093 Lublin, Poland

Phone: +48 509394035

E-mail: mariola.janiszewska@gmail.com 